OPEN ACCESS

Edited by:

Ali Mobasheri,

University of Oulu, Finland

Reviewed by:

Ilaria lacopetti,

University of Padua, Italy

Anna-Rita Attili,

University of Camerino, Italy

*Correspondence:

Livia Camargo Garbin

livia.garbin@gmail.com;

Livia.Garbin@sta.uwi.edu

Specialty section:

This article was submitted to Comparative and Clinical Medicine,

a section of the journal

Frontiers in Veterinary Science

Received: 15 December 2020

Accepted: 12 February 2021

Published: 31 March 2021

Citation:

Camargo Garbin L, Lopez C and

Carmona JU (2021) A Critical Overview of the Use of Platelet-Rich

Plasma in Equine Medicine Over the Last Decade.

Front. Vet. Sci. 8:641818.

doi: 10.3389/fvets.2021.641818

\section{A Critical Overview of the Use of Platelet-Rich Plasma in Equine Medicine Over the Last Decade}

\author{
Livia Camargo Garbin $^{1 *}$, Catalina Lopez ${ }^{2}$ and Jorge U. Carmona ${ }^{2}$ \\ ${ }^{1}$ Department of Veterinary Clinical Sciences, Faculty of Medical Sciences, School of Veterinary Medicine, The University of \\ the West Indies at St. Augustine, St. Augustine, Trinidad and Tobago, ${ }^{2}$ Grupo de Investigación Terapia Regenerativa, \\ Departamento de Salud Animal, Universidad de Caldas, Manizales, Colombia
}

In the 1990s, the role of platelets in inflammation and tissue healing was finally recognized. Since then, the clinical use of platelet-derived products (hemocomponents), such as, platelet-rich plasma (PRP), markedly increased. The promise of a more economical option of a disease-modifying treatment led to the intensive and continuous research of PRP products and to its widespread clinical use. A number of protocols and commercial kits have been developed with the intention of creating a more practical and reliable option for clinical use in equine patients. Still, the direct comparison between studies is particularly challenging due to the lack of standardization on the preparation methods and product composition. The incomplete reports on PRP cellular concentration and the poorly designed in vivo studies are additional matters that contest the clinical efficiency of this biomaterial. To overcome such challenges, several in vitro and in vivo studies have been proposed. Specifically, experiments have greatly focused in protocol optimization and its effect in different tissues. Additionally, in vivo studies have proposed different biological products envisioning the upgrade of the anti-inflammatory cytokines trusting to increase its anti-inflammatory effect. The individual variability and health status of the animal, type of tissue and condition treated, and protocol implemented are known to influence on the product's cell and cytokine composition. Such variability is a main clinical concern once it can potentially influence on PRP's therapeutic effects. Thus, lack of qualitative and quantitative evidence-based data supporting PRP's clinical use persists, despite of the numerous studies intended to accomplish this purpose. This narrative review aims to critically evaluate the main research published in the past decade and how it can potentially impact the clinical use of PRP.

Keywords: platelet-rich plasma, equine, sports medicine, musculoskeletal disease, orthopedics

\section{INTRODUCTION}

The discovery of multiple growth factors (GFs) within platelet's alpha-granules in the 80's (1-3) led to the investigation of platelets as a potential "regenerative" treatment. The significant improvement obtained in reconstruction of large alveolar-mandibular defects in humans (4), and the successful healing of complicated wounds (5) increased the interest for use of platelet-derived products. 
In veterinary medicine, the use of platelet-rich plasma (PRP) started in the field of sports medicine, for the treatment injuries in ligament and tendons (6-8), and it has been used for several veterinary surgical procedures as a biomaterial (9). PRP was used in horses with osteoarthrosis (10), based on previous positive outcomes in humans (11-14). However, controversial results obtained in experimental studies with PRP use in horses $(15,16)$ increased skepticism of the clinical efficiency of PRP. Positive results have been observed from studies with higher chance of bias (17), particularly, in equine studies when compared to human studies (17).

The variation in results obtained in treatments using PRP in both research and clinical scenarios are more likely to be related with its cellular and cytokine profile, as well as its diverse application methods (18). The PRP biologic profile depends on the preparation, which varies in different studies. Additionally, genetic and physiological variability of the equine patients or experimental subjects augments the inconsistency of PRP efficacy among individuals (19). For this reason, several methods of PRP preparation and commercial kits have been proposed for optimization of the product and to develop a more standardized and practical method of delivery and preparation. However, insufficient evidence-based data supporting its clinical use remains. The objective of this review was to critically evaluate the most relevant research published in the past decade and to suggest potential area for improvement in research. Additionally, this review evaluates, compares, and intend to adapt the human PRP classification systems to the methods available for preparation of PRP-products for equine practice.

\section{IN VITRO PLATELET-RICH PLASMA RESEARCH}

In horses, the outcomes with the use of PRP tends to be variable in in vitro experiments, depending on the scenario (20-22). In vitro, the variable effects of PRP can be easily observed depending on cellular content, volume and tissue tested (20-22). This variability can be particularly challenging when treating organs with different types of tissue, such as joints (23). In equine cartilage, higher concentrations of leukocyte and platelet-rich gel (L-PRG) supernatant produced more sustainable release of anabolic factors compared with pure platelet-rich gel (P-PRG) supernatant, under inflammatory conditions (21). Growth factors (GF) such as platelet-derived growth factor-BB (PDGF-BB), transforming growth factor-beta 1 (TGF- $\left.\beta_{1}\right)$, and anti-inflammatory cytokines as interleukin 1 receptor antagonist (IL-1Ra) were observed (21). The dynamic of cytokine release varied according to the cellular content of the platelet-rich gel (PRG) (21). In this case, it is challenging to know if such effects on GF release are due to the higher concentrations of leukocytes or platelets on PRP. Additionally, fibrin content could influence the dynamic of GF release $(22,24)$. In synovium on the other hand, both preparations of allogeneic PRP induced anabolic and anti-inflammatory effect, but leukocyte-reduced preparations increased gene expression of chondrogenic factors (22). In Gilbertie et al. (20) synoviocytes stimulated with LPS and treated with allogeneic platelet-rich lysate (PRP-L) protected chondrocytes challenged with synoviocyte-conditioned media. This effect correlated with an increase in anti-inflammatory cytokine compared to reduction in pro-inflammatory mediators in synoviocyte media (20).

In synovial cells suspended in fluid, PRP resulted in higher prostaglandin E $2\left(\mathrm{PGE}_{2}\right)$ concentration but conversely, increased concentrations of IL-1Ra and decreased oxidative stress (15). It is important to note that the type of synovial cell though, was not well-defined. Another important factor frequently not discussed is the interaction of GFs in tissues which might lead to different outcomes. Previous studies $(21,22)$ suggest that leukocyte concentration within PRP affects cartilage and synovium differently. Once synovium interacts directly with cartilage and plays an important role in osteoarthritis (25), it may be prudent to avoid use of leukocyte-rich PRP in joints.

In normal equine tendon and ligament, platelet-derived products had a different release dynamic of bioactive factors (26). Equine normal suspensory ligament and tendon explants were cultured with different concentrations of leukocyte-reduced platelet-rich gel supernatant (Lr-PRGS) and leukocytereduced plasma supernatant (Lr-PL) (26). Overall lower concentrations of Lr-PRGS induced the most adequate pattern of anti-inflammatory factors in ligament and tendon explants when compared to other hemoderivatives (26). Additionally, leukocyte-reduced platelet products demonstrated more sustainable release of GFs for tendon and ligament explants compared to other platelet-lysate products (26).

In ligaments under inflammatory conditions though, both leukocyte-concentrate and leukocyte-reduce platelet products presented anti-inflammatory effects (27). These studies showed that the anti-inflammatory effects of platelet-derived products might relate to higher concentrations of PDGF-BB in these products $(26,27)$. Both studies showed a significant correlation between levels of PDGF-BB and IL-1Ra release by the tissues $(26,27)$. However, the authors did not show the direct correlation of the increase in IL-1Ra release and inhibition of IL-1 neither its downstream effects on tissue matrix. Further, research is necessary to confirm these assumptions.

\section{IN VIVO PLATELET-RICH PLASMA RESEARCH}

The clinical application of PRP has been more frequently used in the field of equine sports medicine. Particularly in tendons (28) and ligament injuries, application of PRP has been overall successful. In mechanically induced lesions of the superficial digital flexor tendon (SDFT), intralesional injections of PRP were performed 7 days after trauma (28). Treated tendons presented significantly more production of collagen, glycosaminoglycan and cellularity compared to controls (28). The use of PRP in this experiment also improved tissue organization and biomechanical properties compared to placebo (28). Tendons treated with PRP were more metabolically active and showed an advanced repair after 23 weeks (28). The improvement in collagenous matrix organization was also observed through computerized analysis 
of ultrasonographic images in a similar study (29). The authors believed that the earlier resolution of inflammation and the improved callus formation observed in PRP-treated tendons, resulted in better repair tissue in later stages of the healing process when compared to control (29).

In naturally occurring tendinopathies of the SDFT (30), PRP was injected up to 8 weeks after clinical onset. Lameness decreased significantly 8 weeks after treatment, while in control groups, this was observed at 12 weeks, although no difference in cross-sectional area was observed (30). Eighty percent of PRPtreated horses reached their previous levels of performance or higher, 12 months after treatment, while control horses reached similar level in 24 months (30).

Leukocyte-rich PRP demonstrated significant clinical improvement when used on sesamoiditis associated with suspensory ligament branch desmitis (31). Horses in this group were significantly more likely to start racing in a short-term after treatment compared to controls (31). However, there was no difference between groups when races were performed in a long-term after treatment (31).

In equine normal joints, platelet-derived product (Equine Platelet Enhancement Therapy, E-PET, Pall Corporation), activated with thrombin induced an inflammatory response, whereas, platelets activated with $\mathrm{CaCl}_{2}$ did not (32). The synovial fluid levels of PDGF and TGF- $\beta_{1}$ were low after platelet application, thus authors believe the overall positive effects of this therapy may not be attributed to local changes in PDGF and TGF- $\beta_{1}$ concentration (32). Furthermore, GF concentration increased significantly after contact with synovial fluid, which may indicate that exogenous activation of PRP may be unnecessary (32).

Concerning joint disease, variable results have been obtained in clinical improvement when platelet-related products are used for moderate to severe osteoarthritis (33). Although, PRP presented anti-oxidant effects in joints, it also increased $\mathrm{PGE}_{2}$ concentration and decreased quality of hyaluronic acid in synovial fluid after $48 \mathrm{~h}$ of treatment (15). For this reason, the authors suggested caution with the use of PRP is osteochondritis dissecans, immediately after surgery (15).

In bone healing, PRP increased bone consolidation one month after injection in a comminuted diaphyseal fracture of the tibia in a donkey. Delayed bone consolidation and a bone gap were observed 50 days after surgery, although the animal manifested good clinical condition. Authors concluded that PRP was effective as an adjuvant therapy in bone healing (34).

The interest in using this therapy in other systems increased due to PRP prevalent use in sports medicine. In skin wounds, controversial results have been observed $(16,35)$. While this treatment did not influence on formation of collagen types I and III, during the healing process of wounds (35), in other studies PRP favored the formation of excessive granulation tissue, which significantly slowed wound healing up to 3 weeks after creation of the lesion (16). Controversially, in another study, PRP treatment did reduce healing time in wounds on the distal limb of horses, but only in $41.67 \%$ of the cases (36). It is known that second intention wound healing in horses may be more problematic compared to other species (8). The formation of exuberant granulation tissue delays healing, and is especially common in limb wounds where the lesions of the aforementioned studies were induced (37).

Promising results with the use of PRP were obtained in endometritis cases in mares $(38,39)$. Significant decrease in fluid and polymorphonuclear cell influx were observed in mares with different levels of endometritis treated with PRP $4 \mathrm{~h}$ after artificial insemination, compared with cycles which the mares were untreated (38). When applied either before or after artificial insemination, PRP also reduced polymorphonuclear cell infiltrate and cyclo-oxygenase 2 (COX-2) labelled cell compared with control mares $(38,39)$. Overall, the authors believed PRP reduced inflammatory response in mares with persistent matinginduced endometritis $(38,39)$.

The anti-inflammatory effect of PRP seems to rely in different mechanisms that are slowly being clarified. Platelet-rich plasma was able to inhibit nuclear factor Kappa B (NF-кB) $(40,41)$ a key pathway activated during the inflammatory process $(42,43)$. Additionally, PRP reduced chemotaxis to polymorphonuclear cells due to the increase of lipoxin A4 and other chemokines (44-46). Such effects could result in downregulation of important proinflammatory mediators such as TNF- $\alpha$, IL-1, and COX-2, observed in various inflammatory processes (47).

Inconsistency in results obtained in PRP research is a frequent concern. The type of cases and lesions being treated are highly inconsistent (48). There is also a lack of substantial information regarding the standardization and characterization of clinical protocols using PRP. Typically, when cell count is performed on in PRP products, only platelet and in some occasions white blood cell (WBC) numbers are reported. Insufficient characterization of WBC within PRP was observed in previous studies $(28,30)$. It is well-known that the types of leukocytes (i.e., neutrophil) can potentially lead to an increase in pro-inflammatory response (49). Finally, when describing cytokine composition of PRP and growth factor content, authors frequently report PDGF and TGF- $\beta_{1}$. Although, high concentrations of TGF- $\beta_{1}$ (1, $2,19,21)$ and PDGF $(19,21,50)$ are found in PRP, other growth factors and cytokines are also abundant $(21,51-$ 53), and are not frequently studied despite their role in tissue physiology.

The activity or use of the animals and low number of horses are additional factors increasing variability $(30,38,39)$ in PRP research. Lack of proper control groups or standard therapeutic comparisons are other pitfalls frequently observed in clinical studies with the use of PRP (33). Based on such issues, different alternatives have been proposed in research. Studies proposed to compare the treated animal to itself before and after treatment (54). Another alternative was to perform analgesia on the affected limb (peripheral nerve block) and compare the treated horse to itself before and after analgesia (33). Finally, it was proposed to compare the treated horses to other animals of same age, sex, activity, and athlete performance as controls (48). The short duration of the studies, not allowing proper time for tissue repair was another pitfall identified (55). Better research practices in PRP research are paramount for obtaining reliable results that support clinical use of PRP. 
TABLE 1 | Systems proposed for platelet-rich plasma classification in human regenerative medicine (2010-2020).

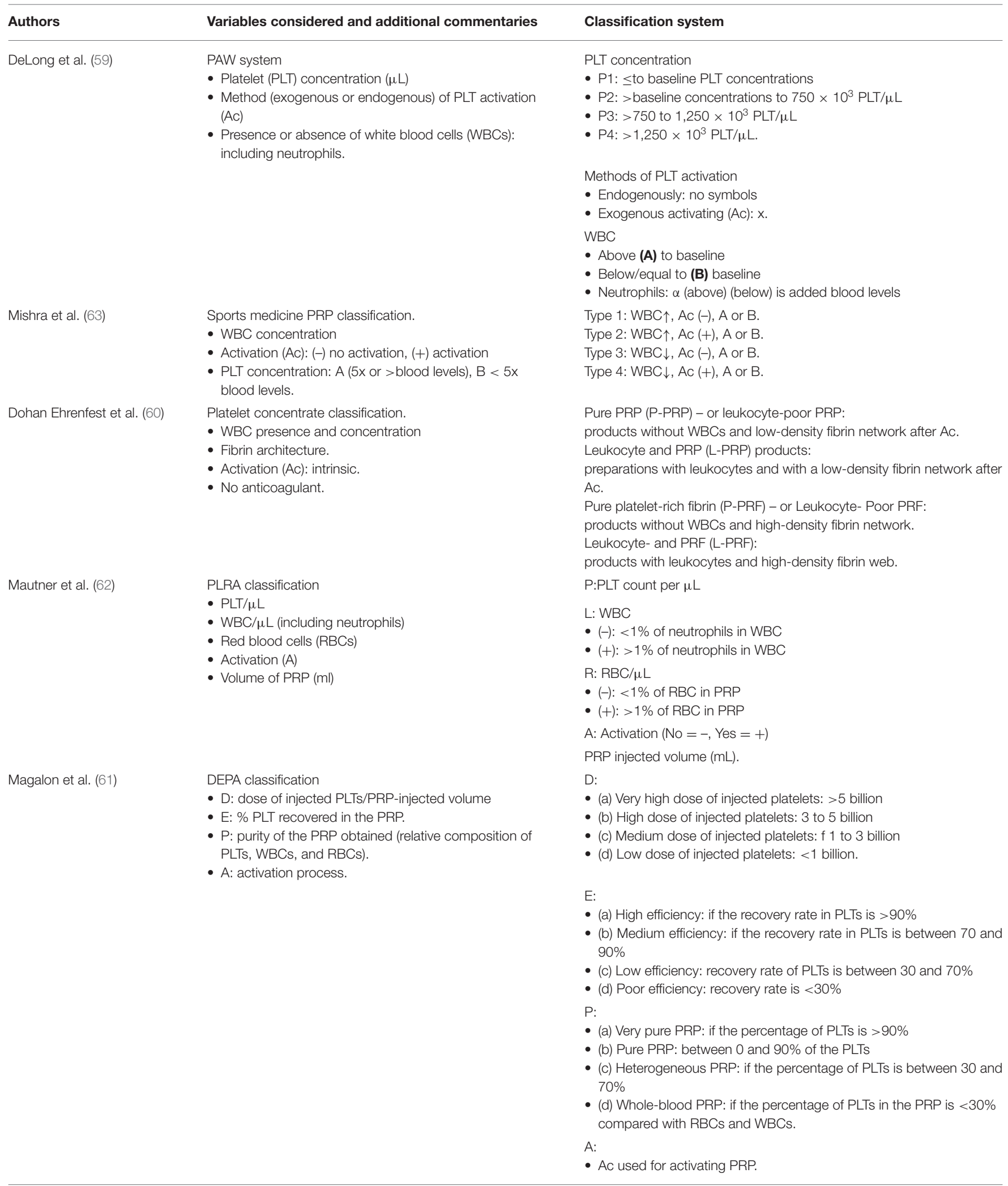


TABLE 1 | Continued

\begin{tabular}{|c|c|c|}
\hline Authors & Variables considered and additional commentaries & Classification system \\
\hline \multirow[t]{3}{*}{ Kon et al. (65) } & $\begin{array}{l}\text { PRP coding system. } \\
\text { - } 6 \text { digits grouped in pairs indicating parameters of PLT } \\
\text { composition, purity and Ac: } N_{1} N_{2}-N_{3} N_{4}-N_{5} N_{6} \text {. }\end{array}$ & $N_{1} \& N_{2}$ indicate the PLT concentration of PRP. \\
\hline & & $\begin{array}{l}N_{3} \& N_{4} \text { indicate the purity of the PRP, referring to the absence }(0) \text { or } \\
\text { presence (1) of RBCs and the concentration of WBCs }(0,1,2,3 \ldots) \text {. }\end{array}$ \\
\hline & & $\begin{array}{l}N_{5} \text { and } N_{6} \text { refer to the activation. } \\
\text { - } N_{5} \text { indicates if activation is endogenous ( } 0 \text { ) or if PRP is activated before } \\
\text { its injection (1). } \\
\text { - } N_{6} \text { mentions the addition of calcium for activation ( } 0=\text { no, } 1=\text { yes). }\end{array}$ \\
\hline
\end{tabular}

PLT, platelet; WBC, white blood cell; Activation, AC.

It is imperative to analyze some aspects related with PRPderived products before taking into consideration the different methods that aim to produce PRP. Below, the classification of PRP in the human regenerative medicine field, as well as the methods used for preparation of PRP in equine practice will be revised.

\section{CLASSIFICATION OF PLATELET CONCENTRATES IN HUMAN REGENERATIVE MEDICINE}

An intense debate for a consensus definition and classification of the plethora of PRP-related products of clinical use persists in the scientific community in the past decade $(8,56-62)$. From Mishra et al. (63) to Kon et al. (64), different classifications methods have been proposed for human PRP. Although PRP has been widely used in veterinary medicine, no valid standardized classification methods for platelet-derived products were proposed. The increase use of PRP by veterinarians showed the urge to stablish important aspects of PRP preparation and application $(58,59,65)$. A standard classification system and procedures for its application in veterinary practice shall improve comparison among clinical studies evaluating the efficacy of PRP. To note, a recent study of PRP in humans found that only $10 \%$ of the studies provided detailed information of PRP preparation methods (65). Additionally, only $16 \%$ of the studies presented quantitative analysis on the composition of PRP (65).

Currently, there are several classification systems for human PRP-related products. These classifications include the description of platelets and leukocytes (including the type and number of leukocyte subpopulations), activation methods, and the final volume of plasma in PRP (65). In general, it can be concluded that these PRP classification systems are useful to document effectively the PRP used in experimental and clinical situations. These methods aim to segregate what is the ideal PRP-hemocomponent, for a particular tissue, in specific clinical scenarios $(62,64)$. A comprehensive synopsis of the most relevant classification proposals for PRPrelated products in human regenerative medicine is presented in Table 1.
At this point, we made a search of experimental, hematological, and clinical equine PRP studies intending to found the specific concentration of each cell type of each evaluated PRP in order to classify these PRP-related products according to some human PRP classification (see Tables 2, 3).

\section{EQUINE PRP-RELATED HEMOCOMPONENTS}

The first research papers related with PRP characterization and clinical use in horses were published over 17 years ago (72). The most significant research performed in the field have been published over the last decade. In general, PRP can be obtained through three methods: automated, semiautomated, and manual procedures (73). At this point, it is important to clarify that eventually PRP can be defined as a volume of plasma containing different concentrations of platelets and leukocytes. Platelet-rich plasma will always have a small quantity of an anticoagulant to prevent platelet activation and clot formation prior to its clinical use (60). On the other hand, platelet-rich fibrin (PRF) is a biomaterial obtained from centrifuged blood without any anticoagulant added (74). Platelet-rich fibrin is a firm platelet gel that can be used as a biomaterial in many surgical procedures, although it is not easily injected $(60,75)$.

To the knowledge of the authors, no studies involving the use of automated cell separators for the preparation of PRP in horses have been published in the past decade. It is important to mention that the first description of the use of these type of devices for PRP production was performed by Carter et al. (72). This PRP product was prepared by using $1 \mathrm{~L}$-bags with $\mathrm{ACD}-\mathrm{A}$ as anticoagulant and a blood cell separator device (72).

With regard to the semi-automated methods, several devices or specialized kits have been described for producing equine PRP (66-69, 76). In general, these kits include a system for collecting blood from the patient, a sterile blood recipient for PRP production and a device for centrifugation (73). There is one method that does not require centrifugation in which PRP is obtained by gravity [E-PET ${ }^{\mathrm{TM}}(67-69)$. Some of these kits have been validated and adjusted for equine blood, whereas others have been used with no modification of the original centrifugation protocol used for human blood (73). Table 2 
TABLE 2 | Semiautomated methods used for PRP production from equine blood and potential classification according to the systems proposed for human PRP classification.

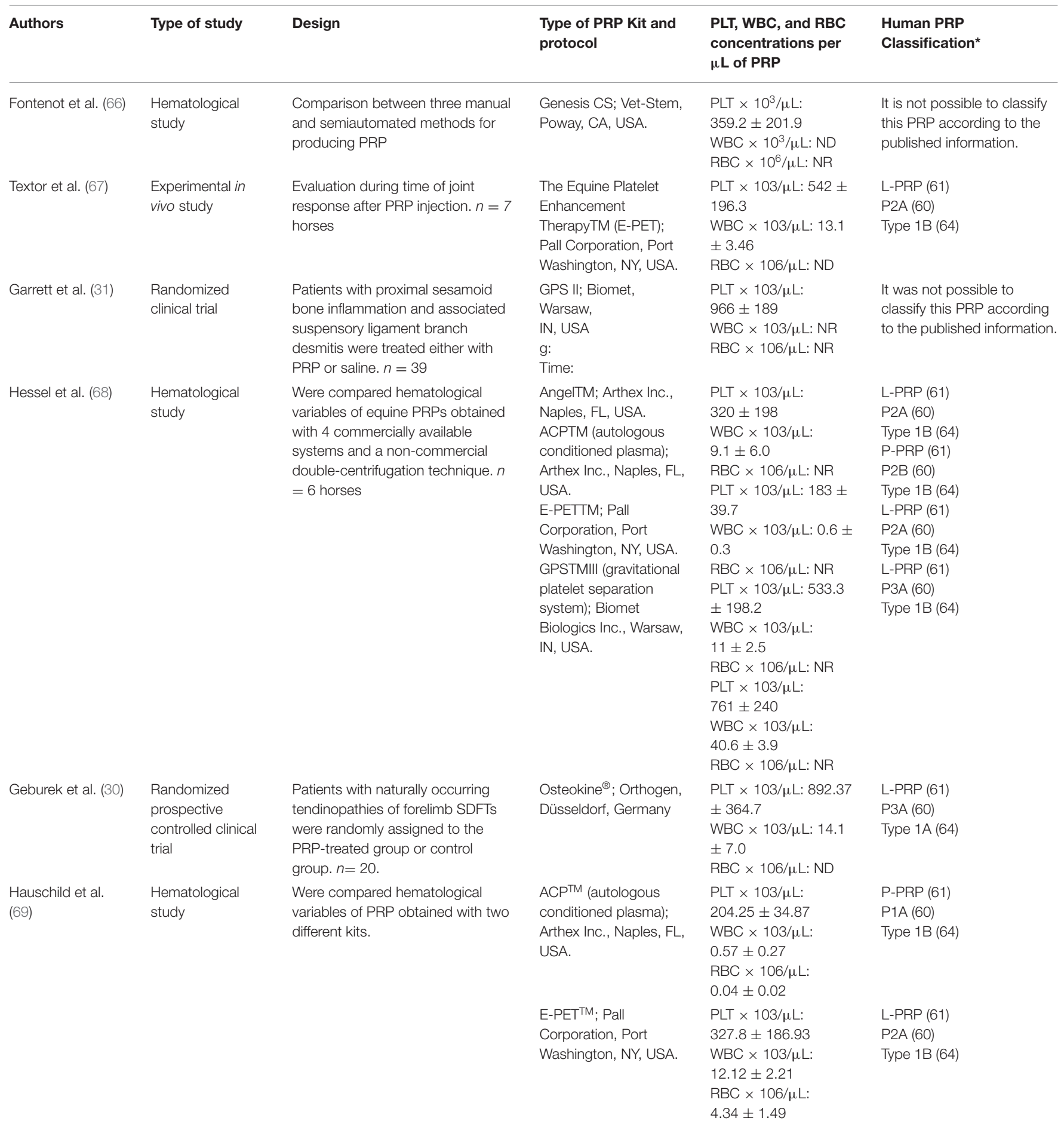

PLT, platelet; WBC, white blood cell; RBC, red blood cell.

*For acronym mean, please see Table 1.

presents a summary of the laboratory, in vivo and clinical studies performed in which PRP semiautomated kits were evaluated. There is a lack of substantial information related to cell composition of the PRP produced by semiautomated procedures. Consequently, proposing or to adapt human classification methods to equine PRP becomes challenging. It is important to 
TABLE 3 | Manual methods used for PRP production from equine blood and potential classification according to the systems proposed for human PRP classification.

\begin{tabular}{|c|c|c|c|c|c|}
\hline Authors & Type of study & Design & $\begin{array}{l}\text { Tubes and other } \\
\text { materials used for } \\
\text { PRP protocol }\end{array}$ & $\begin{array}{l}\text { PLT, WBC, and RBC } \\
\text { concentrations per } \\
\mu L \text { of PRP }\end{array}$ & $\begin{array}{l}\text { Human PRP } \\
\text { Classification* }\end{array}$ \\
\hline & & & & $\begin{array}{l}\mathrm{PLT} \times 10^{3} / \mu \mathrm{L}: \\
399.4 \pm 157.1 \\
\text { WBC } \times 10^{3} / \mu \mathrm{L}: \mathrm{ND} \\
\mathrm{RBC} \times 10^{6} / \mu \mathrm{L}: \mathrm{NR}\end{array}$ & \\
\hline Maciel et al. (70) & $\begin{array}{l}\text { Experimental in } \\
\text { vivo study }\end{array}$ & Evaluation of PRP in equine burns. & $\begin{array}{l}15 \mathrm{~mL} \text { Falcon tubes } \\
\text { containing } 10 \% \text { sodium } \\
\text { citrate. Centrifugation } \\
\text { at } 300 \mathrm{~g} / 10 \mathrm{~min}\end{array}$ & $\begin{array}{l}\mathrm{PLT} \times 10^{3} / \mu \mathrm{L}: 723.0 \pm \\
50 \\
\mathrm{WBC} \times 10^{3} / \mu \mathrm{L}: \mathrm{NR} \\
\mathrm{RBC} \times 10^{6} / \mu \mathrm{L}: \mathrm{NR}\end{array}$ & $\begin{array}{l}\text { It was no possible to classify } \\
\text { this PRP according to the } \\
\text { published information. }\end{array}$ \\
\hline Giraldo et al. (19) & $\begin{array}{l}\text { Hematological } \\
\text { study }\end{array}$ & $\begin{array}{l}\text { Evaluation of the effect of intrinsic } \\
\text { factors on equine PRP. } n=40\end{array}$ & $\begin{array}{l}\text { 8.5- } \mathrm{mL} \text { ACD-A tubes } \\
\text { that were centrifuged } \\
\text { two times at } 120 \\
\mathrm{~g} / 5 \mathrm{~min} \text { and } 240 \\
\mathrm{~g} / 5 \mathrm{~min} .\end{array}$ & $\begin{array}{l}\mathrm{PLT} \times 10^{3} / \mu \mathrm{L}: \\
304.3 \pm 43.9 \\
\text { WBC } \times 10^{3} / \mu \mathrm{L}: \\
4.3 \pm 2.2 \\
\mathrm{RBC} \times 10^{6} / \mu \mathrm{L}: 0.14 \\
\pm 0.1\end{array}$ & $\begin{array}{l}\text { P-PRP (61) } \\
\text { P2B (60) } \\
\text { Type 1B (64) }\end{array}$ \\
\hline Hessel et al. (68) & $\begin{array}{l}\text { Hematological } \\
\text { study }\end{array}$ & $\begin{array}{l}\text { Were compared hematological } \\
\text { variables of equine PRPs obtained } \\
\text { with } 4 \text { commercially available } \\
\text { systems and a non-commercial } \\
\text { double-centrifugation technique. } \\
n=6 \text { horses. }\end{array}$ & $\begin{array}{l}60-\mathrm{mL} \text { syringe } \\
\text { containing } 8 \mathrm{~mL} \text { of } \\
\text { ACD-A. } \\
10-\mathrm{mL} \text { plain glass } \\
\text { tubes } \\
\text { Centrifugated two } \\
\text { times at } 300 \mathrm{~g} / 10 \mathrm{~min} \text {. }\end{array}$ & $\begin{array}{l}\mathrm{PLT} \times 10^{3} / \mu \mathrm{L}: \\
310.4 \pm 164.5 \\
\mathrm{WBC} \times 10^{3} / \mu \mathrm{L}: \\
18.2 \pm 11.8 \\
\mathrm{RBC} \times 10^{6} / \mu \mathrm{L}: \mathrm{NR}\end{array}$ & $\begin{array}{l}\text { L-PRP (61) } \\
\text { P2A (60) } \\
\text { Type 1B (64) }\end{array}$ \\
\hline
\end{tabular}

"For acronym mean, please see Table 1.

highlight that only one paper presented a complete description of the platelets, leukocytes and red blood cells for PRP using two different semiautomated devices (69).

Several manual methods have been proposed for PRP elaboration from equine blood $(19,66,68,70,77)$. In general, these protocols include one or two centrifugation steps (73). Firstly, blood can be collected directly in standard tubes containing anticoagulants (i.e., sodium citrate) or blood bags containing citrate dextrose solution A (ACD-A). Secondly, blood is easily placed in conical tubes and centrifuged for preparation of PRP. Table 3 presents the most frequent manual methods used clinically in horses in which a complete hematological information is provided.

\section{CONTROVERSIAL ASPECTS FOR PRODUCING EQUINE PLATELET-DERIVED HEMOCOMPONENTS IN CLINICAL AND FIELD CONDITIONS}

Equine practitioners are frequently faced with several questions about the selection of the most adequate method or device for producing equine PRP. It is paramount to mention that a strict aseptic technique is necessary during the whole process. The main source for bacterial contamination during PRP preparations is; the skin of the patient, the flora from the clinician's hands and upper respiratory tract, and the environmental bacteria. Thus, the risks associated to potential 
bacterial PRP contamination or PRP-associated infections could be diminished by using a high standard sterile technique. Manipulating the blood in a dust-free environment with minimal air currents are important practices to augment safety for PRP application (78).

Equine practitioners are faced with selecting the most suitable method or device for obtaining PRP in their particular conditions. This election relies on several patient-associated factors, such as, the tissue or organ to be treated, lesion, breed, gender, age, and health status (19). Among the extrinsic factors, financial restraints, the availability of equipment, and adequacy of the facility should be considered.

In general, manual methods intended for PRP production present lower cost, but are time-consuming and require a highquality centrifuge. Semiautomated kits on the other hand are regularly expensive but frequently more practical. The decision of the methods to use will depend on the extrinsic factors discussed and on the PRP demand. For clinicians that work in clinics and do have a significant demand for PRP treatment, it might be profitable in a long term to acquire a high-precision centrifuge. In cases where clinicians work mainly in the field, it would be more indicated to use semiautomated kits or even gravity-filtration systems (E-PET/V-PET). Other alternative would be to simply purchase the platelet products from laboratories that provide such services.

\section{FINAL CONSIDERATIONS}

Several in vivo and in vitro experiments have shown beneficial effects of platelet-related products in modulation of the

\section{REFERENCES}

1. Kaplan DR, Chao FC, Stiles CD, Antoniades HN, Scher CD. Platelet alpha granules contain a growth factor for fibroblasts. Blood. (1979) 53:104352. doi: 10.1182/blood.V53.6.1043.1043

2. Assoian RK, Komoriya A, Meyers CA, Miller DM, Sporn MB. Transforming growth factor-beta in human platelets. Identification of a major storage site, purification, and characterization. J Biol Chem. (1983) 258:715560. doi: 10.1016/S0021-9258(18)32345-7

3. Karey KP, Sirbasku DA. Human platelet-derived mitogens. II Subcellular localization of insulinlike growth factor I to the alpha-granule and release in response to thrombin. Blood. (1989) 74:1093-100. doi: 10.1182/blood.V74.3.1093.bloodjournal7431093

4. Marx RE, Carlson ER, Eichstaedt RM, Schimmele SR, Strauss JE, Georgeff KR. Platelet-rich plasma: Growth factor enhancement for bone grafts. Oral Surg Oral Med Oral Pathol Oral Radiol Endod. (1998) 85:63846. doi: 10.1016/S1079-2104(98)90029-4

5. Mazzucco L, Medici D, Serra M, Panizza R, Rivara G, Orecchia S, et al. The use of autologous platelet gel to treat difficult-to-heal wounds: a pilot study. Transfusion. (2004) 44:1013-8. doi: 10.1111/j.1537-2995.2004.03366.x

6. Waselau M, Sutter WW, Genovese RL, Bertone AL. Intralesional injection of platelet-rich plasma followed by controlled exercise for treatment of midbody suspensory ligament desmitis in Standardbred racehorses. J Am Vet Med Assoc. (2008) 232:1515-20. doi: 10.2460/javma.232.10.1515

7. Sampson S, Gerhardt M, Mandelbaum B. Platelet rich plasma injection grafts for musculoskeletal injuries: a review. Curr Rev Musculoskelet Med. (2008) 1:165-74. doi: 10.1007/s12178-008-9032-5

8. Tambella AM, Attili AR, Dupré G, Cantalamessa A, Martin S, Cuteri $\mathrm{V}$, et al. Platelet-rich plasma to treat experimentaly-induced skin wounds inflammatory process and tissue healing. To optimize PRP composition and facilitate its preparation, numerous methods have been described. Although, the literature in PRP is extensive, lack of evidence and consensus about what method or PRP composition to use in different disease or tissue trauma remains.

Although, the literature in equine PRP is vast, standard information about PRP composition, activation, and application methods are frequently lacking. This limitation prevents or limits the adaption of the classification methods used for PRP in humans to be used in equine platelet products. At this point, the creation of a particular system for PRP classification in horses is of paramount importance to improve, refine, and address new basic and clinical research in this growing research field.

A more detailed information about the methods of preparation, application and composition of the products used in equine research should be encouraged and strongly asked to be included for new equine PRP studies.

\section{AUTHOR CONTRIBUTIONS}

All the authors listed have made a substantial and direct intellectual contribution to the work. All authors have read and approved the manuscript for publication.

\section{ACKNOWLEDGMENTS}

The authors (CL and JC) thank the Vicerrectoría de Investigaciones y Postgrados of the Universidad de Caldas, Manizales, Colombia. in animals: a systematic review and meta-analysis. PLoS ONE. (2018) 13:e0191093. doi: 10.1371/journal.pone.0191093

9. Perinelli DR, Bonacucina G, Pucciarelli S, Cespi M, Serri E, Polzonetti V, et al. Rheological properties and growth facotrs content of platelet-rich plasma: revelenace in veterinary biomedical treatments. Biomedicines. (2020) 8:429. doi: 10.3390/biomedicines8100429

10. Tyrnenopoulou P, Diakakis N, Karayannopoulou M, Savvas I, Koliakos G. Evaluation of intra-articular injection of autologous platelet lysate (PL) in horses with osteoarthritis of the distal interphalangeal joint. Vet Q. (2016) 36:56-62. doi: 10.1080/01652176.2016.1141257

11. Kon E, Buda R, Filardo G, Di Martino A, Timoncini A, Cenacchi A, et al. Platelet-rich plasma: intra-articular knee injections produced favorable results on degenerative cartilage lesions. Knee Surg Sports Traumatol Arthrosc. (2010) 18:472-9. doi: 10.1007/s00167-009-0940-8

12. Filardo G, Kon E, Buda R, Timoncini A, Di Martino A, Cenacchi A, et al. Platelet-rich plasma intra-articular knee injections for the treatment of degenerative cartilage lesions and osteoarthritis. Knee Surg Sports Traumatol Arthrosc. (2011) 19:528-35. doi: 10.1007/s00167-010-1238-6

13. Patel S, Dhillon MS, Aggarwal S, Marwaha N, Jain A. Treatment with platelet-rich plasma is more effective than placebo for knee osteoarthritis: a prospective, double-blind, randomized trial. Am J Sports Med. (2013) 41:35664. doi: 10.1177/0363546512471299

14. Cole BJ, Karas V, Hussey K, Pilz K, Fortier LA. Hyaluronic acid versus platelet-rich plasma: a prospective, double-blind randomized controlled trial comparing clinical outcomes and effects on intra-articular biology for the treatment of knee osteoarthritis. Am J Sports Med. (2017) 45:33946. doi: 10.1177/0363546516665809

15. Machado TSL, Massoco CO, Silva LC, Fülber J, Moreira JJ, Baccarin RYA. Effects of blood-derived products and sodium hyaluronate on equine synovial 
fluid cells and on synovial fluid from osteochondrotic joints of horses after arthroscopy and administration of treatment. Am J Vet Res. (2019) 80:64656. doi: 10.2460/ajvr.80.7.646

16. Monteiro SO, Lepage OM, Theoret CL. Effects of platelet-rich plasma on the repair of wounds on the distal aspect of the forelimb in horses. Am J Vet Res. (2009) 70:277-82. doi: 10.2460/ajvr.70.2.277

17. Brossi PM, Moreira JJ, Machado TS, Baccarin RY. Platelet-rich plasma in orthopedic therapy: a comparative systematic review of clinical and experimental data in equine and human musculoskeletal lesions. BMC Vet Res. (2015) 11:98. doi: 10.1186/s12917-015-0403-z

18. Garbin LC, Olver CS. Platelet-rich products and their application to osteoarthritis. J Equine Vet Sci. (2020) 86:102820. doi: 10.1016/j.jevs.2019.102820

19. Giraldo CE, López C, Álvarez ME, Samudio IJ, Prades M, Carmona JU. Effects of the breed, sex, and age on cellular content and growth factor release from equine pure-platelet rich plasma and pure-platelet rich gel. BMC Vet Res. (2013) 9:29. doi: 10.1186/1746-6148-9-29

20. Gilbertie JM, Long JM, Schubert AG, Berglund AK, Schaer TP, Schnabel LV. Pooled platelet-rich plasma lysate therapy increases synoviocyte proliferation and hyaluronic acid production while protecting chondrocytes from synoviocyte-derived inflammatory mediators. Front Vet Sci. (2018) 5:150. doi: $10.3389 /$ fvets.2018.00150

21. Ríos DL, López C, Carmona JU. Evaluation of the anti-inflammatory effects of two platelet-rich gel supernatants in an in vitro system of cartilage inflammation. Cytokine. (2015) 76:505-13. doi: 10.1016/j.cyto.2015.07.008

22. Carmona JU, Ríos DL, López C, Álvarez ME, Pérez JE. Proinflammatory and anabolic gene expression effects of platelet-rich gel supernatants on equine synovial membrane explants challenged with lipopolysaccharide. Vet Med Int. (2017) 2017:6059485. doi: 10.1155/2017/6059485

23. Loeser RF, Goldring SR, Scanzello CR, Goldring MB. Osteoarthritis: a disease of the joint as an organ. Arthritis Rheum. (2012) 64:1697707. doi: 10.1002/art.34453

24. Dohan Ehrenfest DM, Rasmusson L, Albrektsson T. Classification of platelet concentrates: from pure platelet-rich plasma (P-PRP) to leucocyte- and platelet-rich fibrin (L-PRF). Trends Biotechnol. (2009) 27:158-67. doi: 10.1016/j.tibtech.2008.11.009

25. Belluzzi E, Stocco E, Pozzuoli A, Granzotto M, Porzionato A, Vettor R, et al. Contribution of intrapatellar fat pad and synovial membrane to knee osteoarthritis pain. Biomed Res Int. (2019) 2019:6390182. doi: 10.1155/2019/6390182

26. Bonilla-Gutiérrez AF, Castillo-Franz C, López C, Álvarez ME, Giraldo $\mathrm{CE}$, Carmona JU. Equine suspensory ligament and tendon explants cultured with platelet-rich gel supernatants release different antiinflammatory and anabolic mediators. Biomed Pharmacother. (2018) 108:476-85. doi: 10.1016/j.biopha.2018.09.065

27. Castillo-Franz CLC, Alvarez ME, Giraldo CE, Carmona JU. Antiinflammatory effects of two platelet-rich gel supernatants in an in vitro system of ligament desmitis. Muscle Ligament Tendon J. (2019) 9:11. doi: $10.32098 / \mathrm{mltj} .04 .2019 .04$

28. Bosch G, van Schie HT, de Groot MW, Cadby JA, van de Lest CH, Barneveld A, et al. Effects of platelet-rich plasma on the quality of repair of mechanically induced core lesions in equine superficial digital flexor tendons: a placebo-controlled experimental study. J Orthop Res. (2010) 28:211-7. doi: 10.1002/jor.20980

29. Bosch G, René van Weeren P, Barneveld A, van Schie HT. Computerised analysis of standardised ultrasonographic images to monitor the repair of surgically created core lesions in equine superficial digital flexor tendons following treatment with intratendinous platelet rich plasma or placebo. Vet J. (2011) 187:92-8. doi: 10.1016/j.tvjl.2009.10.014

30. Geburek F, Gaus M, van Schie HT, Rohn K, Stadler PM. Effect of intralesional platelet-rich plasma (PRP) treatment on clinical and ultrasonographic parameters in equine naturally occurring superficial digital flexor tendinopathies - a randomized prospective controlled clinical trial. BMC Vet Res. (2016) 12:191. doi: 10.1186/s12917-016-0826-1

31. Garrett KS, Bramlage LR, Spike-Pierce DL, Cohen ND. Injection of plateletand leukocyte-rich plasma at the junction of the proximal sesamoid bone and the suspensory ligament branch for treatment of yearling Thoroughbreds with proximal sesamoid bone inflammation and associated suspensory ligament branch desmitis. J Am Vet Med Assoc. (2013) 243:1205. doi: 10.2460/javma.243.1.120

32. Textor JA.,Willits NH, Tablin F. Synovial fluid growth factor and cytokine concentrations after intra-articular injection of a platelet-rich product in horses. Vet J. (2013) 198:217-23. doi: 10.1016/j.tvjl.2013.07.020

33. Mirza MH, Bommala P, Richbourg HA, Rademacher N, Kearney MT, Lopez MJ. Gait changes vary among horses with naturally occurring osteoarthritis following intra-articular administration of autologous platelet-rich plasma. Front Vet Sci. (2016) 3:29. doi: 10.3389/fvets.2016.00029

34. Faillace V, Tambella AM, Fratini M, Paggi E, Dini F, Laus F. Use of autologous platelet-rich plasma for a delayed consolidation of a tibial fracture in a young donkey. J Vet Med Sci. (2017) 79:618-22. doi: 10.1292/jvms.16-0400

35. de Souza MV, Silva MB, de Oliveira Pinto J, de Souza Lima MB, Crepaldi J, Lopes GF, et al. Immunohistochemical expression of collagens in the skin of horses treated with leukocyte-poor platelet-rich plasma. Biomed Res Int. (2015) 2015:893485. doi: 10.1155/2015/893485

36. Carneiro da Fontoura Pereira R, De La Corte FD, Brass KE, da Silva Azevedo M, Gallio M, Cantarelli C, et al. Evaluation of three methdos of platelet-rich plasma for treatment of equine distal limb skin wounds. J Equine Vet Sci. (2019) 72:1-7. doi: 10.1016/j.jevs.2017.10.009

37. Serensen MA, Petersen LJ, Bundgaard L, Toft N, Jacobsen S. Reginonal disturbences in blood flow and metabolism in equine limb wound healing with formation of exuberant granulation tissue. Wound Repair Regen. (2014) 22:647-53. doi: 10.1111/wrr.12207

38. Segabinazzi LG, Friso AM, Correal SB, Crespilho AM, Dell'Aqua JA Jr, Miró J, et al. Uterine clinical findings, fertility rate, leucocyte migration, and COX2 protein levels in the endometrial tissue of susceptible mares treated with platelet-rich plasma before and after AI. Theriogenology. (2017) 104:1206. doi: 10.1016/j.theriogenology.2017.08.007

39. Reghini MFS, Ramires Neto C, Segabinazzi LG, Castro Chaves MM, de Paula F Dell'Aqua C, Bussiere MCC, et al. Inflammatory response in chronic degenerative endometritis mares treated with platelet-rich plasma. Theriogenology. (2016) 86:516-22. doi: 10.1016/j.theriogenology.2016.01.029

40. Ghosh S, Hayden MS. New regulators of NF-kappaB in inflammation. Nat Rev Immunol. (2008) 8:837-48. doi: 10.1038/nri2423

41. Perkins ND. Post-translational modifications regulating the activity and function of the nuclear factor kappa B pathway. Oncogene. (2006) 25:671730. doi: 10.1038/sj.onc.1209937

42. Alam R, Forsythe PA, Lett-Brown MA, Grant JA. Interleukin-8 and RANTES inhibit basophil histamine release induced with monocyte chemotactic and activating factor/monocyte chemoattractant peptide- 1 and histamine releasing factor. Am J Respir Cell Mol Biol. (1992) 7:42733. doi: $10.1165 / \mathrm{ajrcmb} / 7.4 .427$

43. El-Sharkawy H, Kantarci A, Deady J, Hasturk H, Liu H, Alshahat M, et al. Platelet-rich plasma: growth factors and pro- and anti-inflammatory properties. J Periodontol. (2007) 78:661-9. doi: 10.1902/jop.2007.060302

44. Sundman EA, Cole BJ, Karas V, Della Valle C, Tetreault MW, Mohammed $\mathrm{HO}$, et al. The anti-inflammatory and matrix restorative mechanisms of platelet-rich plasma in osteoarthritis. Am J Sports Med. (2014) 42:3541. doi: $10.1177 / 0363546513507766$

45. Woodell-May J, Matuska A, Oyster M, Welch Z, O'Shaughnessey K, Hoeppner J. Autologous protein solution inhibits MMP-13 production by IL-1 $\beta$ and TNF $\alpha$-stimulated human articular chondrocytes. J Orthop Res. (2011) 29:1320-6. doi: 10.1002/jor.21384

46. Bendinelli P, Matteucci E, Dogliotti G, Corsi MM, Banfi G, Maroni P, et al. Molecular basis of anti-inflammatory action of platelet-rich plasma on human chondrocytes: mechanisms of NF-кB inhibition via HGF. J Cell Physiol. (2010) 225:757-66. doi: 10.1002/jcp.22274

47. Metcalf K, Scoggin K, Troedsson Mht. The effect of platelet-rich plasma on endometrial pro-inflammatory cytokines in susceptible mares following semen deposition. J Equine Vet Sci. (2012) 32. doi: 10.1016/j.jevs.2012.06.065

48. Witte S, Dedman C, Harriss F, Kelly G, Chang YM, Witte TH. Comparison of treatment outcomes for superficial digital flexor tendonitis in National Hunt racehorses. Vet J. (2016) 216:157-63. doi: 10.1016/j.tvjl.2016.08.003

49. Boswell SG, Schnabel LV, Mohammed HO, Sundman EA, Minas T, Fortier LA. Increasing platelet concentrations in leukocyte-reduced platelet-rich plasma decrease collagen gene synthesis in tendons. Am J Sports Med. (2014) 42:429. doi: $10.1177 / 0363546513507566$ 
50. Linder BL, Chernoff A, Kaplan KL, Goodman DS. Release of platelet-derived growth factor from human platelets by arachidonic acid. Proc Natl Acad Sci U S A. (1979) 76:4107-11. doi: 10.1073/pnas.76.8.4107

51. Amable PR, Carias RB, Teixeira MV, da Cruz Pacheco I, Corrêa do Amaral RJ, Granjeiro JM, et al. Platelet-rich plasma preparation for regenerative medicine: optimization and quantification of cytokines and growth factors. Stem Cell Res Ther. (2013) 4:67. doi: 10.1186/scrt218

52. Boswell SG, Cole BJ, Sundman EA, Karas V, Fortier LA. Plateletrich plasma: a milieu of bioactive factors. Arthroscopy. (2012) 28:42939. doi: 10.1016/j.arthro.2011.10.018

53. Textor JA, Norris JW, Tablin F. Effects of preparation method, shear force, and exposure to collagen on release of growth factors from equine platelet-rich plasma. Am J Vet Res. (2011) 72:271-8. doi: 10.2460/ajvr.72.2.271

54. Giunta K, Donnell JR, Donnell AD, Frisbie DD. Prospective randomized comparison of platelet rich plasma to extracorporeal shockwave therapy for treatment of proximal suspensory pain in western performance horses. Res Vet Sci. (2019) 126:38-44. doi: 10.1016/j.rvsc.2019.07.020

55. Fukuda K, Miyata H, Kuwano A, Kuroda T, Tamura N, Kotoyori Y, et al. Does the injection of platelet-rich plasma induce changes in the gene expression and morphology of intact thoroughbred skeletal muscle? J Equine Sci. (2017) 28:31-9. doi: 10.1294/jes.28.31

56. Acebes-Huerta A, Arias-Fernández T, Bernardo Á, Muñoz-Turrillas MC, Fernández-Fuertes J, Seghatchian J, et al. Platelet-derived bio-products: classification update, applications, concerns and new perspectives. Transfus Apher Sci. (2020) 59:102716. doi: 10.1016/j.transci.2019.102716

57. Alves R, Grimalt R. A review of platelet-rich plasma: history, biology, mechanism of action, and classification. Skin Appendage Disord. (2018) 4:1824. doi: 10.1159/000477353

58. Amin I, Gellhorn AC. Platelet-rich plasma use in musculoskeletal disorders: are the factors important in standardization well-understood? Phys Med Rehabil Clin N Am. (2019) 30:439-49. doi: 10.1016/j.pmr.2018.12.005

59. DeLong JM, Russell RP, Mazzocca AD. Platelet-rich plasma: the PAW classification system. Arthroscopy. (2012) 28:9981009. doi: 10.1016/j.arthro.2012.04.148

60. Dohan Ehrenfest DM, Andia I, Zumstein MA, Zhang CQ, Pinto NR, Bielecki T. Classification of platelet concentrates (Platelet-Rich Plasma-PRP, Platelet-Rich Fibrin-PRF) for topical and infiltrative use in orthopedic and sports medicine: current consensus, clinical implications and perspectives. Muscles Ligaments Tendons J. (2014) 4:3-9. doi: 10.11138/mltj/2014. 4.1 .0013

61. Magalon J, Chateau AL, Bertrand B, Louis ML, Silvestre A, Giraudo L, et al. DEPA classification: a proposal for standardising PRP use and a retrospective application of available devices. BMJ Open Sport Exerc Med. (2016) 2:e000060. doi: 10.1136/bmjsem-2015-000060

62. Mautner K, Malanga GA, Smith J, Shiple B, Ibrahim V, Sampson S, et al. A call for a standard classification system for future biologic research: the rationale for new PRP nomenclature. Pm r. (2015) 7(Suppl. 4):S539. doi: 10.1016/j.pmrj.2015.02.005

63. Mishra A, Harmon K, Woodall J, Vieira A. Sports medicine applications of platelet rich plasma. Curr Pharm Biotechnol. (2012) 13:1185-95. doi: 10.2174/138920112800624283

64. Dohan A, Harmon K, Woodall J, Vieira A. Sports medicine applications of platelet rich plasma. Curr Pharm Biotechnol. (2012) 13:1185-95. doi: 10.2174/138920112800624283

65. Kon E, Di Matteo B, Delgado D, Cole BJ, Dorotei A, Dragoo JL, et al. Platelet-rich plasma for the treatment of knee osteoarthritis: an expert opinion and proposal for a novel classification and coding system. Expert Opin Biol Ther. (2020):1-14. doi: 10.1080/14712598.2020. 1798925
66. Fontenot RL, Sink CA, Werre SR, Weinstein NM, Dahlgren LA. Simple tube centrifugation for processing platelet-rich plasma in the horse. Can Vet J. (2012) 53:1266-72.

67. Textor JA, Tablin F. Intra-articular use of a platelet-rich product in normal horses: clinical signs and cytologic responses. Vet Surg. (2013) 42:499510. doi: 10.1111/j.1532-950X.2013.12015.x

68. Hessel LN, Bosch G, van Weeren PR, Ionita JC. Equine autologous platelet concentrates: a comparative study between different available systems. Equine Vet J. (2015) 47:319-25. doi: 10.1111/evj.12288

69. Hauschild G, Geburek F, Gosheger G, Eveslage M, Serrano D, Streitbürger A, et al. Short term storage stability at room temperature of two different platelet-rich plasma preparations from equine donors and potential impact on growth factor concentrations. BMC Vet Res. (2017) 13:7. doi: 10.1186/s12917-016-0920-4

70. Maciel FB, De Rossi R, Módolo TJ, Pagliosa RC, Leal CR, Delben AA. Scanning electron microscopy and microbiological evaluation of equine burn wound repair after platelet-rich plasma gel treatment. Burns. (2012) 38:105865. doi: 10.1016/j.burns.2012.02.029

71. Moraes AP, Moreira JJ, Brossi PM, Machado TS, Michelacci YM, Baccarin RY. Short- and long-term effects of platelet-rich plasma upon healthy equine joints: clinical and laboratory aspects. Can Vet J. (2015) 56:831-8.

72. Carter CA, Jolly DG, Worden CE Sr, Hendren DG, Kane CJ. Platelet-rich plasma gel promotes differentiation and regeneration during equine wound healing. Exp Mol Pathol. (2003) 74:24455. doi: 10.1016/S0014-4800(03)00017-0

73. Carmona JU, Lopez C, Sandoval JA. Review of the currently available systems to obtain platelet related products to treat equine musculoskeletal injuries. Recent Pat Regenerat Med. (2013) 3:148-59. doi: 10.2174/2210296511303020005

74. Jiménez-Aristizabal RF, López C, Álvarez ME, Giraldo C, Prades M, Carmona JU. Long-term cytokine and growth factor release from equine platelet-rich fibrin clots obtained with two different centrifugation protocols. Cytokine. (2017) 97:149-55. doi: 10.1016/j.cyto.2017.06.011

75. Jiménez-Aristazábal RF, Carmona JU, Prades M. Changes on the structural architecture and growth factor release, and degradation in equine platelet-rich fibrin clots cultured over time. J Equine Vet Sci. (2019) 82:102789. doi: $10.1016 /$ j.jevs.2019.102789

76. Textor JA, Tablin F. Activation of equine platelet-rich plasma: comparison of methods and characterization of equine autologous thrombin. Vet Surg. (2012) 41:784-94. doi: 10.1111/j.1532-950X.2012.01016.x

77. Miranda S, Costa MFM, Reboucas N, Ramos MT, Lessa DAB, Alencar NX. Protocols for preparation of platelet rich plasma (PRP) in Quarter Horses. Pesq Vet Bras. (2019) 39:614-21. doi: 10.1590/1678-5150-pvb-5883

78. Alvarez ME, Giraldo CE, Carmona JU. Monitoring bacterial contamination in equine platelet concentrates obtained by the tube method in a clean laboratory environment under three different technical conditions. Equine Vet J. (2010) 42:63-7. doi: 10.2746/042516409X455221

Conflict of Interest: The authors declare that the research was conducted in the absence of any commercial or financial relationships that could be construed as a potential conflict of interest.

Copyright (c) 2021 Camargo Garbin, Lopez and Carmona. This is an open-access article distributed under the terms of the Creative Commons Attribution License (CC $B Y)$. The use, distribution or reproduction in other forums is permitted, provided the original author(s) and the copyright owner(s) are credited and that the original publication in this journal is cited, in accordance with accepted academic practice. No use, distribution or reproduction is permitted which does not comply with these terms. 